include bacterial infections such as anthrax and erysipelas, with the result that ample evidence of the importance of phagocytosis as a means of disposal of intrusive bacterial elements was forthcoming.

Metchnikoff was fortunate in his choice of scientific associates and of the milieu in which his life-work was done. On his first visit to Pasteur in 1887 he was kindly received and was offered a laboratory in the then newly built Institute in the Rue Dutot, whereas, soon afterwards, Koch in Berlin and Emmerich in Munich gave him such a cool reception that he decided to accept Pasteur's offer, and thus in October 1888 he entered the most fruitful period of his career, which lasted until his death in 1916 at the age of seventy-one.

The controversies on the rival doctrines of immunity upheld by the French and the German schools-which, on one side at least, gave the impression of national partisanship-are now of merely historical interest. The humoral theory to which the German workers obstinately clung was based on the direct bactericidal action of the blood-serum of normal and, in particular, of immunized animals. The view now held is that active phagocytosis depends upon sensitization of the bacteria by bacteriotropic substances that are present in normal and immune sera. The two points of view are thus by no means mutually hostile; they are indeed complementary and their relative importance varies with the particular instance of an infective process that is chosen for illustration. After Metchnikoff's death, Aschoff and other workers systematized the cellular theory of immunity by defining the types of cells scattered throughout the tissues and organs of the body that are capable of functioning as phagocytes; these form the so-called reticulo-endothelial system of cells. This scheme of classification has conduced to precision and convenience of description. Recent studies of phagocytosis have been numerous and have been directed towards elucidating the finer mechanisms of the process as revealed by physical and physicochemical methods. The romantic attribution to the phagocytes of purposeful activities as defenders of the citadel of life against bacterial invaders, which so impressed the popular mind in the last decades of the nineteenth century, has given place to more prosaic interpretations. Experimental work has thrown light on such problems as the part played by the nature of the surface of the particles exposed to phagocytosis; the influence of the $p \mathrm{H}$. of the surrounding medium upon the exposed particles and upon the phagocytes; the influence of temperature, of surface forces, and of the viscosity of the cell protoplasm upon the intake of particles; and the differences that are observed in the functional activity of leucocytes when these are collected from healthy and diseased subjects.

Metchnikoff's researches included studies on the comparative pathology of inflammation, a process in which phagocytosis is one of the chief manifestations. His observations on chemotaxis and on intracellular digestion of bacteria engulfed by the phagocytes have not been disturbed by the newer knowledge. There still remains, however, for solution the refractory problem of the deviations from the normal of the biochemical activities within the local phagocytes and fixed tissue cells; these changes must be assumed to vary both in quality and degree throughout the phases of the inflammatory process until the lesion has healed.
The general interest aroused by his work on the transmission of syphilis to chimpanzees and on the prophylaxis of the experimental disease by the inunction of mercurial ointment is still remembered. Metchnikoff had a passion for probing into the mysteries of life and death, as is shown by his own mental reaction to his approaching dissolution, but it would seem that in his views on the production of senile changes in the tissues caused, as he thought, by intoxication from harmful intestinal bacteria, his imaginative powers outran his judgment ; the habit of drinking sour milk as a preventive measure against ill-health and premature old age has now disappeared. Nevertheless, his work has encouraged the important study of the physiology and pathology of senescence, and within recent years this subject has engaged the attention of an enthusiastic group of scientific workers in the United States and also in Great Britain.

Metchnikoff was international in outlook both as a man of science and as a humanist, and here it is worth quoting a sentence from the warmly expressed tribute of Emile Roux, his friend and colleague, on the occasion of Metchnikoff's seventieth birthday. "Resté Russe de nationalité, vous êtes devenu Français par votre choix et vous avez contracté avec l'Institut Pasteur une alliance franco-russe, longtemps avant que les diplomates en aient eu l'idée."

Is it, perhaps, too fanciful to believe that the farreaching speculations of Metchnikoff were influenced by the early impressions which he formed when as a boy he viewed with the eyes of a born naturalist the boundless steppes that surrounded his village home near Kharkoff ? He can never lose his place among the company of the pioneers of experimental medicine.

\section{Dr. B. M. Griffiths}

Dr. B. Mintard Griffrths, who died on March 25, was born at Kidderminster in 1887, and studied at the University of Birmingham during the years 1905-8; he took the D.Sc. degree of that University in 1923. Towards the end of the War of 1914-18 he was assistant to Prof. Yapp at Belfast, but in October of 1920 he was appointed lecturer at Newcastle and afterwards, in 1924, became reader in charge of the new botanical laboratories established at Durham, which he placed upon a secure footing.

His early work concerned the giant bacteria belonging to the genus Hillhousia and was carried out in conjunction with G. T. West, but most of his scientific investigations related to the Algæ. Already in 1912 he published a paper on the Algæ of Stanklin Pool and in 1915 a morphological study of Glaucocystis, while afterwards he turned his attention chiefly to planktonic and limnological studies. We owe to him a considerable number of data on the phytoplankton of the lowland pools of Britain contained in a number of papers published in the Linnean Society's Journal.

He took some part in the foundation of the Freshwater Biological Association and for several years represented the University of Durham on its Council. During the later years of his life he suffered much from ill-health, and this no doubt contributed materially to reduce his output of scientific work, which showed considerable promise.

F. E. Fritsch. 